\title{
Gesegmenteerde informatie en alternatieve winstbegrippen
}

\section{Arjan Brouwer en Chris Knoops}

SAMENVATTING $0 \mathrm{p}$ basis van IFRS 8 is de interne managementinformatie leidend voor de extern te rapporteren segmentinformatie. In de praktijk leidt dit tot de rapportage in die segmentinformatie van alternatieve winstbegrippen die door het management zelf gedefinieerd zijn en die afwijken van door IFRS voorgeschreven winstbegrippen. Een duidelijke omschrijving die de lading dekt en aansluiting tussen de gehanteerde alternatieve winstbegrippen en het geconsolideerde IFRS resultaat zijn belangrijke aandachtspunten voor transparante informatieverschaffing over de segmentprestaties. Wij constateren dat op dit vlak verbetering mogelijk is door posten die buiten het segmentresultaat blijven niet geaggregeerd en samengevoegd met de resultaten van de kleinere segmenten te rapporteren binnen een segment Overig, maar als onderdeel van een afzonderlijke aansluiting.

\section{RELEVANTIE VOOR DE PRAKTIJK Inzicht in de prestaties van de segmenten van} een onderneming is van belang om de risico's en groeimogelijkheden goed in te schatten. Hiervoor is transparantie over de samenstelling van de per segment gerapporteerde winstbegrippen van belang. Het onderzoek laat zien dat dit nog verbetering behoeft.

\section{Inleiding}

Voor de meeste ondernemingen ${ }^{1}$ is IFRS primair gericht op de geconsolideerde jaarrekening. Weliswaar bevat IAS 27 bepalingen voor de enkelvoudige jaarrekening, maar hierin wordt ook aangegeven dat IFRS de opname van een enkelvoudige jaarrekening niet voorschrijft. IFRS schrijft het opstellen van een geconsolideerde jaarrekening voor tenzij gebruik gemaakt kan worden van een specifieke vrijstelling, maar of daarnaast een enkelvoudige jaarrekening wordt opgesteld, wordt over het algemeen bepaald door lokale wettelijke vereisten, zoals in Nederland BW 2 Titel 9.

De geconsolideerde jaarrekening heeft als doel om inzicht te geven in de prestaties en financiële situatie van de gehele groep. Dit inzicht is voor veel gebruikers van belang voor het nemen van hun beslissingen en is over het algemeen beter te verwerken voor de gebruikers van de jaar- rekening dan separate informatie over iedere individuele entiteit binnen die groep. Geconsolideerde cijfers geven echter geen inzicht in de prestaties van verschillende bedrijfsonderdelen en verminderen daarmee het inzicht in de samenstelling van omzet, winst, activa en verplichtingen. Inzicht in die samenstelling kan bijvoorbeeld van belang zijn om de groeimogelijkheden en risico's binnen de groep in te schatten. Om die reden is gesegmenteerde informatie een belangrijke aanvulling op geconsolideerde informatie ten behoeve van het nemen van beslissingen door gebruikers (zie ook Dijksma \& Schoonderbeek, 2001). Knoops en Dijksma (1996) geven aan dat segmentatie de mogelijkheid biedt om te komen tot een betere beoordeling van de prestaties van de onderneming, tot een betere schatting van de risico's en rendementen en tot het beter nemen van economische beslissingen door financieel analisten en (potentiële) beleggers.

IFRS 8 Operationele segmenten is sinds 2009 van toepassing en bevat de vereisten die gelden voor de opname van gesegmenteerde informatie in de jaarrekening die is opgesteld op basis van IFRS. Het algemene uitgangspunt van deze standaard is verwoord in IFRS 8.1 en wordt herhaald in IFRS 8.20: "Een entiteit moet informatie verschaffen om gebruikers van haar jaarrekeningen in staat te stellen de aard en de financiële gevolgen te evalueren van de bedrijfsactiviteiten die zij uitoefent en de economische gebieden waarin zij opereert."

Een belangrijk uitgangspunt in deze standaard is de zogenoemde managementbenadering. Voor de extern te rapporteren segmentinformatie wordt bij deze benadering aangesloten bij de interne managementinformatie die door het management ("de hoogstgeplaatste functionaris die belangrijke operationele beslissingen neemt" of "Chief Operating Decision Maker", hierna CODM) wordt gebruikt voor het beoordelen van de financiële prestaties en het toekennen van middelen. In dit artikel gaan we in op een specifiek aspect van deze benadering, namelijk de rapportage over de prestaties van de segmenten. We doen onderzoek naar het gebruik van alternatieve winstbegrippen als onderdeel van deze rapportage en naar de transparantie van de informatieverschaffing over die winstbegrippen. 
In paragraaf 2 gaan we nader in op de managementbenadering van IFRS 8 en een aantal specifieke bepalingen die hieruit voortvloeien. Tevens gaan we in op literatuur en regelgeving met betrekking tot het gebruik van alternatieve winstbegrippen. In paragraaf 3 doen we verslag van empirisch onderzoek naar de informatieverschaffing rondom prestatiemaatstaven die worden gerapporteerd als onderdeel van de segmentinformatie. In paragraaf 4 sluiten we af met een conclusie.

\section{Regelgeving en literatuur over gesegmenteerde informatie en alternatieve winstbegrippen}

\subsection{IFRS 8: de managementbenadering}

Zoals hiervoor aangegeven gaat IFRS 8 uit van een managementbenadering voor gesegmenteerde informatie waarbij de interne organisatiestructuur en managementinformatie het uitgangspunt zijn voor de extern te rapporteren gesegmenteerde informatie. Dit is een wijziging ten opzichte van de situatie van voor 2009 toen in IAS 14 het risico- en rendementsprofiel het uitgangspunt was. Beide benaderingen hebben voor- en nadelen. In de Basis for Conclusions bij IFRS 8 geeft de International Accounting Standards Board (IASB) bijvoorbeeld aan dat de meeste partijen die commentaar hebben gegeven op de Exposure Draft van IFRS 8 de managementbenadering ondersteunen omdat het gebruikers de mogelijkheid geeft om de activiteiten te beoordelen vanuit hetzelfde perspectief als het management en dit geeft meer inzicht in de wijze waarop het management de activiteiten aanstuurt. Andere respondenten vonden vergelijkbaarheid belangrijker en gaven de voorkeur aan de oude aanpak die uitging van het risico- en rendementsprofiel van de activiteiten. Ook Knoops en Dijksma (1996) geven vanwege vergelijkbaarheid de voorkeur aan die methode. In het Discussion Paper "A Review of the Conceptual Framework for Financial Reporting” (IASB, 2013a) wordt, naast verminderde vergelijkbaarheid, ook minder neutrale rapportage genoemd als mogelijk nadeel van de managementbenadering. Het zou management mogelijk meer vrijheid geven om beleidskeuzes te maken ten aanzien van de rapportage van segmentinformatie en zo de informatie op de voor haar meest gunstige wijze te presenteren. Een tussenvorm die door respondenten op de Exposure Draft ook is voorgesteld is een aanpak waarbij de segmentindeling wordt bepaald op basis van de interne structuur, maar de te rapporteren maatstaven en de bepaling van de omvang ervan vergelijkbaar dienen te zijn en bepaald dienen te worden op basis van IFRS. Dijksma en Schoonderbeek (2001) spreken van een dilemma voor de IASB waarbij het gedetailleerd voorschrijven van segmentatie-eisen kan leiden tot het gelijkmaken van wat niet gelijk is of juist kan leiden tot betere vergelijkbaarheid. Aansluiting van de externe rapportage op de interne rapportage kan het inzicht verbeteren en de informatie nuttiger maken voor het nemen van beslissingen omdat juist op basis van verschillen beslissingen worden genomen.

De IASB heeft, mede ten behoeve van het bereiken van convergentie met US GAAP, besloten om de managementbenadering te volgen in IFRS 8 en zowel voor de identificatie van de segmenten als voor de bepaling van de te rapporteren maatstaven voor resultaat, activa en passiva aan te sluiten bij de intern gerapporteerde informatie. Hierbij geeft de IASB aan dat de nadelen van het gebruik van door het management zelf, op een nietIFRS basis, bepaalde maatstaven niet opwegen tegen de voordelen zoals de mogelijkheid voor ondernemingen om snel en eenvoudig tot informatieverschaffing te komen en voor de gebruiker om inzicht te krijgen in de aansturing door het management. Een belangrijke overweging van de IASB hierbij wordt geformuleerd in IFRS 8, BC14. De IASB stelt hier dat de opgenomen vereisten om de wijze waarop het segmentresultaat is bepaald uiteen te zetten en een aansluiting op te nemen tussen de segmentresultaten en het geconsolideerde IFRS resultaat, de gebruiker in staat zal stellen om goed te begrijpen en beoordelen hoe de segmentresultaten zijn bepaald. Backhuijs en Camfferman (2011) constateren dat veel ondernemingen in de praktijk bepaalde posten buiten het segmentresultaat laten en geven dan ook aan dat de inzichtelijkheid van deze aansluiting een belangrijk aandachtspunt is bij de toepassing van de standaard.

De basis waarop segmentresultaten worden bepaald en hoe deze zich verhouden tot het geconsolideerde IFRSresultaat blijkt in de praktijk echter moeilijk te doorgronden. In juli 2013 heeft de IASB haar rapportage uitgebracht naar aanleiding van de post-implementation review van IFRS 8 (IASB, 2013) en ook hierin wordt ingegaan op een aantal aandachtspunten voortvloeiend uit de managementbenadering. Gebruikers geven aan dat ze moeite hebben met de diversiteit in resultaatbegrippen die worden gehanteerd, met het doorgronden van de aansluitingen die worden opgenomen en hoe ze deze kunnen relateren aan de individuele segmenten. Ondernemingen geven aan dat ze niet goed begrijpen hoe ze exact de vereiste aansluitingsinformatie moeten weergeven. Hier staat tegenover dat met de invoering van IFRS 8 over het algemeen de segmentinformatie in de jaarrekening en de informatie in het jaarverslag beter op elkaar aansluiten (Backhuijs \& Camfferman, 2011; IASB, 2013) wat de informatie begrijpelijker kan maken voor de gebruikers.

De IASB rapporteert dat een aantal partijen zorgen heeft over het gebruik van resultaatmaatstaven die niet op een IFRS-basis zijn bepaald of waar bepaalde IFRSelementen buiten zijn gelaten. Inconsistentie in de 
definitie van begrippen tussen ondernemingen en (on) duidelijkheid over de samenstelling van resultaatmaatstaven komen in het feedback statement (IASB, 2013b) terug als aandachtspunten. Deze discussie en de aandachtspunten rondom het gebruik van deze zogenaamde alternatieve winstbegrippen zijn niet nieuw. In de volgende paragraaf gaan we hier nader op in.

\subsection{Alternatieve winstbegrippen}

Het gebruik van alternatieve winstbegrippen is sinds eind jaren negentig sterk toegenomen. Als we naar $\mathrm{Ne}$ derland kijken dan melden Backhuijs en Mertens (2000) op basis van onderzoek van de jaarverslaggeving van 37 Nederlandse beursfondsen bijvoorbeeld dat EBITDA in 1999 voor het eerst wordt waargenomen in Nederland en dat nagenoeg alle ondernemingen één of meer (tot maximaal negen) prestatiemaatstaven rapporteren. In vervolgonderzoek stellen Hooghiemstra en Van der Tas (2003) een toename van het gebruik van alternatieve winstbegrippen vast en ook Brouwer (2007a) constateert deze trend. Wel constateren Hooghiemstra en Van der Tas (2004) in de jaarverslaggeving over 2003 een lichte afname van het gebruik van EBITDA, en specifiek in de winst-en-verliesrekening, wat het gevolg was van verduidelijking door de Raad voor de jaarverslaggeving van de strijdigheid hiervan met het Besluit Modellen Jaarrekening. Marseille en Vergoossen (2005) en Bosman en Vergoossen (2007) onderzoeken daarnaast het gebruik van alternatieve prestatiemaatstaven in Nederlandse persberichten. $\mathrm{Zij}$ constateren eveneens een toename in het gebruik van dergelijke maatstaven en rapporteren daarnaast dat de informatieverstrekking, waaronder een duidelijke aansluiting met een gedefinieerd winstbegrip, in veel gevallen te wensen overlaat waardoor zij de informatie in een aantal gevallen zelfs aanmerken als misleidend.

Een vergelijkbare trend is internationaal zichtbaar. Zie bijvoorbeeld Brouwer (2007b), Brouwer en Gup (2009), Backhuijs en Knoops (2011) en Isidro en Marques (2015) die voor onderzochte populaties met Europese ondernemingen een breed verspreid gebruik van alternatieve winstbegrippen rapporteren en Bhattacharya et al. (2004) en Entwistle et al. (2005) die dit constateren in de Verenigde Staten en Canada.

De reacties van investeerders, regelgevers en toezichthouders op het wijdverspreide gebruik van alternatieve winstbegrippen is tweeledig. Aan de ene kant geven gebruikers van financiële informatie aan dat ze deze informatie nuttig vinden en gebruiken (zie bijvoorbeeld FASB, 2002 en PwC, 2014), maar daar staat tegenover dat veel partijen zich zorgen maken over het ontstaan van een wildgroei aan winstbegrippen, de motieven voor rapportage en de transparantie van de informatievoor- ziening (zie bijvoorbeeld SEC, 2001, IOSCO, 2002, FD, 2004 en CESR, 2005). De wetenschappelijke literatuur laat zien dat gerapporteerde alternatieve winstbegrippen nuttig zijn voor gebruikers, maar ook dat strategische motieven een rol kunnen spelen bij de keuze om een bepaald winstbegrip wel of niet te rapporteren (zie bijvoorbeeld FD, 2013). Ook ten aanzien van regulering van het gebruik van alternatieve winstbegrippen staan regelgevers dus voor een dilemma. Aan de ene kant pleit geconstateerd opportunistisch of strategisch gebruik voor regulering en aan de andere kant dient ervoor gewaakt te worden dat relevante informatie voor gebruikers achterwege wordt gelaten als gevolg van die regulering. Het gebruik van alternatieve winstbegrippen is tot nu toe dan ook niet verboden door regelgevers en toezichthouders. Wel proberen zij via regelgeving de consistentie en transparantie ten aanzien van gerapporteerde winstbegrippen te verbeteren. In dat kader hebben bijvoorbeeld de Securities and Exchange Commission (SEC, 2003) en het Committee of European Securities Regulators (CESR, 2005) regels respectievelijk aanbevelingen uitgebracht die ondernemingen in acht zouden moeten nemen indien zij alternatieve winstbegrippen rapporteren. In 2014 heeft de opvolger van CESR, de European Securities and Markets Authority (ESMA, 2014), een Consultation Paper uitgebracht om input te krijgen op haar voorstellen om de CESRaanbevelingen te herzien.

De keuze voor de managementbenadering in IFRS 8 brengt met zich mee dat ondernemingen alternatieve winstbegrippen moeten rapporteren als dat de winstbegrippen zijn die het management gebruikt om de prestaties van de segmenten te beoordelen. Deze keuze laat dus zien dat de IASB de oplossing niet zoekt in het verbieden van het rapporteren hiervan. Zoals de IASB in IFRS 8, BC14 aangeeft zoekt zij de oplossing in transparante informatie over de gehanteerde winstbegrippen zodat gebruikers van de jaarrekening deze goed kunnen interpreteren. In de volgende paragraaf gaan we nader op deze bepalingen in.

\subsection{Relevante IFRS-bepalingen en andere regelgeving}

IFRS 8, par. 23 schrijft voor dat een entiteit voor elk te rapporteren segment een (waardering van het) resultaat dient te rapporteren. In par. 25 wordt voorts aangegeven dat het bedrag van het gerapporteerde gesegmenteerde resultaat gelijk dient te zijn aan het bedrag dat (de waardering die) is gerapporteerd aan de CODM.

Aanpassingen en eliminaties die worden gemaakt ten behoeve van de geconsolideerde jaarrekening en toerekeningen van opbrengsten, kosten en winsten of verliezen dienen alleen bij de bepaling van het gerapporteerde resultaat van het segment in aanmerking te worden genomen als zij zijn opgenomen in de bepa- 
ling van het resultaat van het segment dat wordt gehanteerd door de CODM. Het is dus niet de bedoeling om puur voor het opstellen van segmentinformatie bepaalde allocaties van overheadkosten te maken als dat voor interne doeleinden ook niet gebeurt.

In dit kader is de definitie van een operationeel segment van belang. Deze definitie is opgenomen in IFRS 8.5:

"Een operationeel segment is een onderdeel van een entiteit:

a. dat bedrijfsactiviteiten uitoefent waaruit opbrengsten kunnen worden verdiend en waarbij kosten kunnen worden gemaakt (met inbegrip van opbrengsten en kosten die met transacties met andere onderdelen van dezelfde entiteit verband houden);

b. waarvan de bedrijfsresultaten regelmatig worden beoordeeld door de hoogstgeplaatste functionaris van de entiteit die belangrijke operationele beslissingen neemt, teneinde beslissingen over de aan het segment toe te kennen middelen te kunnen nemen en de financiële prestaties van het segment te evalueren, en

c. waarover afzonderlijke financiële informatie beschikbaar is."

Belangrijk in deze definitie is dat het onderdeel bedrijfsactiviteiten moet uitoefenen om te kunnen spreken van een operationeel segment. Dat is niet voor ieder onderdeel van een onderneming het geval. Een voorbeeld hiervan kunnen bepaalde hoofdkantoorfuncties zijn of een holdingentiteit waarin bepaalde kosten worden geboekt die niet ten laste komen van de segmenten. Redenen hiervoor kunnen zijn dat men wil dat het management van de segmenten haar beslissingen neemt op basis van het effect van die beslissingen op het resultaat exclusief deze posten of dat het segmentmanagement niet beoordeeld of afgerekend wordt op deze kosten. Dit komt wel voor bij reorganisatiekosten, impairments of specifieke éénmalige posten, maar sommige ondernemingen boeken ook bijvoorbeeld optiekosten of pensioenkosten in een dergelijke holdingentiteit in plaats van in de segmenten. IFRS 8.6 benadrukt dat bijvoorbeeld de hoofdzetel van een onderneming of sommige functionele afdelingen geen opbrengsten genereren of opbrengsten genereren die slechts bijkomstig zijn bij die uit de activiteiten van de entiteit, en daarom geen operationele segmenten zijn. In dat geval zal het resultaat van de segmenten dus een resultaat exclusief deze kosten zijn, een voorbeeld van een alternatief winstbegrip dus. Het is ook mogelijk dat het resultaat van de segmenten op een andere basis wordt bepaald dan op basis van de reguliere IFRS-bepalingen. Zo is het mogelijk dat voor managementinformatiedoeleinden resultaten worden bepaald op basis van historische kosten waar IFRS reële waarde voorschrijft of dat voor managementdoeleinden anders wordt omgegaan met hedge-accounting dan IFRS voorschrijft. Het is zelfs mogelijk dat de interne managementinformatie, en daarmee de segmentinformatie, op een volledig andere grondslag is gebaseerd dan IFRS. Een voorbeeld hiervan is ASM International NV dat de interne managementinformatie baseert op US GAAP en om die reden haar segmentinformatie ook (zie figuur 1).

Rapportage van segmentresultaten op basis van US GAAP is een duidelijk voorbeeld van een waardering van het segmentresultaat op een andere basis dan IFRS. Voor de andere situaties waarbij bepaalde posten buiten het resultaat worden gelaten is minder duidelijk of dat feit nu leidt tot een resultaat op een andere basis dan IFRS of dat nog gesproken kan worden van een alternatief winstbegrip dat verder wel op basis van IFRS is bepaald.

Zoals eerder aangegeven is het van belang dat een onderneming duidelijke informatie geeft op basis waarvan de gebruiker van de jaarrekening zich een goed beeld kan vormen van de basis waarop het segmentresultaat is bepaald en hoe dit zich verhoudt tot het geconsolideerde resultaat. Hiertoe neemt de onderneming de volgende informatie op in de jaarrekening:

- Informatie over het gerapporteerde resultaat van een segment, met inbegrip van bepaalde opbrengsten en kosten die in het gerapporteerde resultaat van het segment zijn opgenomen en de waarderingsgrondslag (IFRS 8.21b).

- Aansluitingen tussen, enerzijds, de totalen van de opbrengsten van de segmenten en het gerapporteerde resultaat van de segmenten en, anderzijds, de overeenkomstige bedragen voor de entiteit zoals opgenomen in de geconsolideerde winst-en-verliesrekening (IFRS 8.21c).

- Indien de CODM meer dan één resultaatmaatstaf (waardering) van een operationeel segment hanteert, dan dienen de gerapporteerde resultaten de resultaatmaatstaven te zijn waarvan het management meent dat zij zijn bepaald in overeenstemming met de waarderingsgrondslagen die het meest consistent zijn met die welke bij de waardering van de overeenkomstige bedragen in de geconsolideerde winst-enverliesrekening zijn gehanteerd (IFRS 8.26).

Figuur 1 Voorbeeld ASMLStatutory annual report 2013, p. 116

Segment performance is evaluated by our CODM based on US GAAP net earnings or loss which in certain respect, as explained in the table below, is measured differently from net income or loss reported in our Consolidated Financial Statements, which are based on IFRS. 
- Voor elk te rapporteren segment een verklaring van de waarderingen van het resultaat van het segment waaronder de aard van eventuele verschillen tussen de waarderingen van het resultaat van de te rapporteren segmenten en het resultaat van de entiteit vóór lasten of baten uit hoofde van winstbelastingen en beëindigde bedrijfsactiviteiten. Deze verschillen kunnen onder meer de grondslagen voor de financiële verslaggeving en de grondslagen voor de toerekening van centraal gemaakte kosten omvatten welke noodzakelijk zijn om inzicht te verwerven in de gerapporteerde gesegmenteerde informatie (IFRS 8.27).

- Het totaal van de waarderingen van het resultaat van de te rapporteren segmenten en het resultaat van de entiteit vóór lasten (of baten) uit hoofde van winstbelastingen en beëindigde bedrijfsactiviteiten. Indien een entiteit aan te rapporteren segmenten posten zoals lasten (baten) uit hoofde van winstbelastingen toerekent, mag zij een aansluiting geven tussen het totaal van de waarderingen van het resultaat van de te rapporteren segmenten en het resultaat van de entiteit na deze posten (IFRS 8.28).

Naast de bestaande bepalingen in IFRS 8 zijn de in 2014 gepubliceerde voorstellen van de IASB en ESMA omtrent het gebruik van alternatieve winstbegrippen en aanvullende tussentellingen relevant om te betrekken in de beoordeling van de transparantie van de informatieverschaffing over alternatieve winstbegrippen in de segmentinformatie. De IASB stelt voor om in IAS 1 de volgende bepalingen op te nemen (IASB, 2014):

- een onderneming neemt extra tussentellingen op in de winst-en-verliesrekening als deze relevante informatie verschaffen aan de gebruiker;

- tussentellingen dienen te bestaan uit posten die verantwoord en gewaardeerd zijn in overeenstemming met IFRS;

- een tussentelling dient aangeduid te worden met een benaming die duidelijk aangeeft waaruit de tussentelling bestaat;

- tussentellingen dienen van periode tot periode consistent gebruikt te worden;

- tussentellingen dienen niet prominenter te worden gepresenteerd dan de in IFRS gedefinieerde winstbegrippen;

- de onderneming dient een aansluiting op te nemen tussen gedefinieerde winstbegrippen en de in de winst-en-verliesrekening opgenomen tussentellingen door iedere post die niet is opgenomen in de tussentelling afzonderlijk te presenteren in de winst-enverliesrekening.

ESMA richt zich op het gebruik van alternatieve winstbegrippen in bredere zin en verwacht dat de volgende zaken in acht worden genomen bij het gebruik van alternatieve winstbegrippen (ESMA, 2014):
- opname van een aansluiting tussen het alternatieve winstbegrip en het meest relevante resultaatbegrip in de jaarrekening;

- uitleg van de context waarin het alternatieve winstbegrip wordt gebruikt zodat de gebruiker de relevantie kan duiden;

- minder nadruk op alternatieve winstbegrippen dan op gedefinieerde winstbegrippen;

- consistent gebruik en opname van vergelijkende cijfers.

Belangrijke aspecten die terugkomen in de verschillende bepalingen en voorstellen zijn een duidelijke benaming die goed weergeeft wat het resultaatbegrip inhoudt en een heldere aansluiting tussen het alternatieve winstbegrip en een gedefinieerd winstbegrip zoals opgenomen in de winst-en-verliesrekening.

In paragraaf 3 doen we verslag van het empirisch onderzoek naar het gebruik van alternatieve winstbegrippen in de segmentinformatie en de mate waarin ondernemingen deze transparantievereisten in acht nemen bij de rapportage van deze alternatieve winstbegrippen.

\section{Resultaten van empirisch onderzoek naar ge- segmenteerde informatie en alternatieve winst- begrippen}

\subsection{Populatie}

Wij hebben de financiële verslagen over 2013 onderzocht van 73 ondernemingen die deel uitmaken van de FTSE Eurotop 100 Index. Van de 99 ondernemingen die zijn opgenomen in deze index hebben wij uitgesloten de 24 financiële instellingen en twee ondernemingen die niet rapporteren op basis van IFRS of op basis van IFRSs die zijn goedgekeurd door de Europese Unie (IFRS-EU). De ondernemingen voldoen daarnaast aan de verslaggevingsvereisten van het land waarin zij beursgenoteerd zijn. In de bijlage zijn de 73 ondernemingen die onze onderzoekspopulatie vormen onderverdeeld naar bedrijfstak en land van herkomst. Elf ondernemingen hebben een gebroken boekjaar; voor deze ondernemingen hebben wij de jaarrekeningen onderzocht van het gebroken boekjaar waarvan de meeste maanden in 2013 vielen (voor 1 onderneming met boekjaar dat loopt van 1 juli tot en met 30 juni hebben wij het financiële jaarverslag 2012/2013 onderzocht).

\subsection{Winstbegrippen in de winst-en-verliesrekening en in het segmentatieoverzicht}

IAS 1 Presentatie van de jaarrekening biedt een grote mate van vrijheid ten aanzien van het presenteren van de resultaten. Volgens IAS 1.85 moet de onderneming additionele posten, kopjes en subtotalen op- 
nemen in de winst-en-verliesrekening (of in het overzicht van gerealiseerde en niet-gerealiseerde resultaten) als dat relevant is voor het inzicht in de prestaties van de onderneming. Ondernemingen nemen in de praktijk veelvuldig dergelijke tussentellingen op in de winst-en-verliesrekening. Voor zover deze tussentellingen betrekking hebben op het resultaat spreken wij van winstbegrippen. In tabel 1 wordt aangegeven hoeveel winstbegrippen in de winst-enverliesrekening zijn opgenomen ${ }^{2}$. In tabel 2 wordt aangegeven welke winstbegrippen door de onderzochte ondernemingen worden gebruikt in de winsten-verliesrekening.

\section{Tabel 1 Aantal gerapporteerde winstbegrippen per} onderneming in winst-en-verliesrekening

\begin{tabular}{|c|c|c|}
\hline & $\mathbf{n}$ & $\%$ \\
\hline 3 & 4 & 5 \\
\hline 4 & 10 & 14 \\
\hline 5 & 15 & 21 \\
\hline 6 & 24 & 33 \\
\hline 7 & 13 & 18 \\
\hline 8 & 6 & 8 \\
\hline 9 & 1 & 1 \\
\hline Totaal & 73 & 100 \\
\hline
\end{tabular}

In paragraaf 2.3 gaven wij aan dat ondernemingen informatie dienen te verschaffen over het gerapporteerde resultaat van een segment (IFRS 8.21b) en dat aansluitingen tussen deze resultaten en de resultaten in de geconsolideerde winst-en-verliesrekening dienen te worden gepresenteerd.

IAS biedt 1 de mogelijkheid om de voor het begrip van de financiële prestaties meest relevante tussentellingen in de winst-en-verliesrekening zelf op te nemen. Het zou daarom ook in de lijn der verwachting liggen dat de winstbegrippen die in de winst-en-verliesrekening worden gerapporteerd door het management ook relevant worden gevonden om intern te gebruiken voor het aansturen van de activiteiten. Daarom hebben wij geïnventariseerd in hoeverre winstbegrippen die voorkomen in de winst-en-verliesrekening ook terugkomen in het segmentatieoverzicht. Het startpunt van deze analyse vormen derhalve de winstbegrippen die worden gerapporteerd in de winst-en-verliesrekening. De resultaten worden gerapporteerd in tabel 2 .

Tabel 2 laat zien dat van de in de winst-en-verliesrekening gerapporteerde winstbegrippen vooral de winstbegrippen die zich 'in het midden' van de winst-en-verliesrekening bevinden worden gerapporteerd in de gesegmenteerde informatie. Vooral begrippen als EBIT en EBITDA komen over het algemeen voor in de segmentinformatie als ze worden gerapporteerd in de winst-en-verliesrekening. Een post als brutowinst die bovenin de winst-enverliesrekening is opgenomen of posten als winst voor belasting (EBT) of nettowinst die laag in de winst-en-verliesrekening zijn opgenomen komen in veel minder gevallen ook terug in de segmentinformatie.

$\mathrm{Bij}$ de door ons onderzochte ondernemingen is het totale resultaat van de individueel gerapporteerde segmenten (voor het segment Overig, zie paragraaf 3.3) dan ook in $86 \%$ van de gevallen hoger dan het nettoresultaat van de onderneming. Gemiddeld is het gerapporteerde segmentresultaat 2,22 keer zo hoog als het nettoresultaat (mediaan 1,6 keer zo hoog).

Backhuijs en Knoops (2011) wijzen op een bijzondere wijze van presenteren die alleen voorkomt bij ondernemingen in het Verenigd Koninkrijk. Deze presentatiewijze waarbij ondernemingen in de winst-en-verliesrekening kolommen of regels opnemen voor bijzondere posten, herwaarderingen, reorganisaties en dergelijke, is nog een overblijfsel van een standaard FRS 3 Reporting Financial Performance. Wij kwamen deze presentatiewijze nog tegen bij vijf ondernemingen uit het Verenigd Koninkrijk. Franse ondernemingen volgen aanbeveling 2009-R03 van de Conseil National de Comptabilité (CNC) van 2 juli 2009 over de presentatie van de jaarrekening voor ondernemingen die IFRSs toepassen (Backhuijs \& Knoops, 2011). Deze aanbeveling is inmiddels vervangen door aanbeveling 2013-03 van de Autorité des Normes Comptables. In deze aanbevelingen worden definities gegeven van het operationeel resultaat en van het résultat opérationnel courant. Het verschil tussen beide winstbegrippen wordt aangeduid met other operating income en dit bestaat uit de bijzondere posten. In de Franse aanbeveling worden specifiek genoemd: boekwinsten of -verliezen bij afstoting van activa of activiteiten, kosten van herstructureringen, waardeverminderingen ${ }^{4}$ (impairments) en rechtsgedingen. Wij treffen dit aan bij 12 voornamelijk Franse ondernemingen.

Ook ondernemingen in andere landen rapporteren bepaalde bijzondere posten in veel gevallen afzonderlijk. In tabel 3 geven wij een overzicht van het aantal bijzondere posten dat ondernemingen afzonderlijk benoemen. Het aantal genoemde bijzondere posten loopt sterk uiteen. In sommige jaarrekeningen zijn de bijzondere posten duidelijk te herkennen omdat ze als zodanig benoemd zijn; in andere jaarrekeningen (b.v. van Franse ondernemingen) zijn ze "verborgen" onder een kopje "other operating income", terwijl wel duidelijk wordt gemaakt dat het gaat om "non-recurring items". 12 (16\%) ondernemingen noemen geen bijzonder posten (special items).

Een voorbeeld van een onderneming die specifiek aangeeft wat voor soort posten zij aanmerkt als bijzondere posten is Reckitt Benckiser (zie figuur 2 op pag. 434). 


\section{Tabel 2 Winstbegrippen in de winst-en-verliesrekening en in het segmentatieoverzicht}

\begin{tabular}{|c|c|c|c|c|c|c|}
\hline \multirow[t]{2}{*}{$\begin{array}{l}\text { Naam winstbegrip in geconsolideerde winst-en-ver- } \\
\text { liesrekening en segmentatieoverzicht }\end{array}$} & \multicolumn{2}{|c|}{$\begin{array}{l}\text { Aantal winstbegrippen } \\
\text { voor totaal onderne- } \\
\text { ming in de winst-en- } \\
\text { verliesrekening }\end{array}$} & \multicolumn{2}{|c|}{$\begin{array}{l}\text { Waarvan: aantal winst- } \\
\text { begrippen voor totaal } \\
\text { onderneming in de } \\
\text { winst-en-verliesrekening } \\
\text { én per segment in het } \\
\text { segmentatie-overzicht }\end{array}$} & \multicolumn{2}{|c|}{$\begin{array}{l}\text { Aantal winstbegrippen } \\
\text { per segment alleen in } \\
\text { segmentatie-overzicht }\end{array}$} \\
\hline & $\mathrm{n}$ & $\%$ & $\mathrm{n}$ & $\%$ & $\mathrm{n}$ & $\%$ \\
\hline Brutowinst & 38 & 52 & 6 & 8 & - & 0 \\
\hline Adjusted EBITDA (excl. resultaat deeln \& jv) & 3 & & 3 & & 10 & \\
\hline Adjusted EBITDA (incl. resultaat deeln \& jv) & - & & - & & 2 & \\
\hline Adjusted EBITDA (geen resultaat deeln \& jv) & - & & - & & 1 & \\
\hline Adjusted EBITDA & 3 & 4 & 3 & 4 & 13 & 18 \\
\hline EBITDA (excl. resultaat deeln \& jv) & 1 & & 1 & & 7 & \\
\hline EBITDA (incl. resultaat deeln \& jv) & - & & - & & - & \\
\hline EBITDA (geen resultaat deeln \& jv) & 1 & & 1 & & - & \\
\hline EBITDA & 2 & 3 & 2 & 3 & 7 & 10 \\
\hline Adjusted EBITA (excl. resultaat deeln \& jv) & 1 & & 1 & & 1 & \\
\hline Adjusted EBITA (incl. resultaat deeln \& jv) & - & & - & & - & \\
\hline Adjusted EBITA (geen resultaat deeln \& jv) & - & & - & & - & \\
\hline Adjusted EBITA & 1 & 1 & 1 & 1 & 1 & 1 \\
\hline EBITA (excl. resultaat deeln \& jv) & 1 & & 1 & & - & \\
\hline EBITA (incl. resultaat deeln \& jv) & - & & - & & 1 & \\
\hline EBITA (geen resultaat deeln \& jv) & - & & - & & - & \\
\hline EBITA & 1 & 1 & 1 & 1 & 1 & 1 \\
\hline Adjusted EBIT (excl. resultaat deeln \& jv) & 15 & & 14 & & 11 & \\
\hline Adjusted EBIT (incl. resultaat deeln \& jv) & 3 & & 1 & & 5 & \\
\hline Adjusted EBIT (geen resultaat deeln \& jv) & 3 & & 3 & & 2 & \\
\hline Adjusted EBIT & 21 & 29 & 18 & 25 & 18 & 25 \\
\hline EBIT (excl. resultaat deeln \& jv) & 41 & & 26 & & - & \\
\hline EBIT (incl. resultaat deeln \& jv) & 19 & & 15 & & - & \\
\hline EBIT (geen resultaat deeln \& jv) & 12 & & 8 & & - & \\
\hline $\begin{array}{l}\text { EBIT (incl. resultaat deeln \& jv) + resultaat op verkoop en } \\
\text { sluiting business unit }\end{array}$ & 1 & & 1 & & - & \\
\hline EBIT & 73 & 100 & 50 & 68 & - & 0 \\
\hline Adjusted EBT (excl. resultaat deeln \& jv) & - & & - & & - & \\
\hline Adjusted EBT (incl. resultaat deeln \& jv) & 3 & & - & & - & \\
\hline Adjusted EBT (geen resultaat deeln \& jv) & - & & - & & - & \\
\hline Adjusted EBT & 3 & 4 & - & 0 & - & 0 \\
\hline
\end{tabular}




\begin{tabular}{|c|c|c|c|c|c|c|}
\hline EBT (excl. resultaat deeln \& jv) & 7 & & - & & - & \\
\hline EBT (incl. resultaat deeln \& jv) & 44 & & 2 & & - & \\
\hline EBT (geen resultaat deeln \& jv) & 12 & & 2 & & - & \\
\hline EBT & 63 & 86 & 4 & 5 & - & 0 \\
\hline Earnings on current cost of supplies basis & - & & - & & 1 & \\
\hline Adjusted net income & 2 & & - & & 1 & \\
\hline Nettowinst, continuing operations & 14 & & 1 & & - & \\
\hline Nettowinst (excl. resultaat deeln. + jv) & 1 & & - & & - & \\
\hline Resultaat op basis van U.S. GAAP & 1 & & 1 & & - & \\
\hline Diverse winstbegrippen & 18 & 25 & 2 & 3 & 2 & 3 \\
\hline Nettowinst & 73 & 100 & 4 & 5 & - & 0 \\
\hline $\begin{array}{l}\text { Adjusted EBITDA van niet-geconsolideerde deelnemingen } \\
\text { en joint ventures (equity method }\end{array}$ & - & & - & & 1 & \\
\hline $\begin{array}{l}\text { Adjusted EBIT van niet-geconsolideerde deeln. \& jv (equi- } \\
\text { ty method) }\end{array}$ & - & & - & & 1 & \\
\hline $\begin{array}{l}\text { Adjusted resultaat niet-geconsolideerde deeln \& jv (equi- } \\
\text { ty method) }\end{array}$ & 1 & & - & & - & \\
\hline $\begin{array}{l}\text { Resultaat niet-geconsolideerde deelnemingen en joint } \\
\text { ventures (equity method) }\end{array}$ & 60 & & 27 & & - & \\
\hline $\begin{array}{l}\text { Resultaat niet-geconsolideerde deelnemingen \& joint } \\
\text { ventures (equity method) }\end{array}$ & 61 & 84 & 27 & 37 & 2 & 3 \\
\hline $\begin{array}{l}\text { Discontinued operations (beëindigde activiteiten, na be- } \\
\text { lastingen) }\end{array}$ & 15 & 21 & - & 0 & - & 0 \\
\hline $\begin{array}{l}\text { Other non-recurring operating income (vnl. Franse on- } \\
\text { dernemingen) }\end{array}$ & 12 & & 2 & & - & \\
\hline $\begin{array}{l}\text { Special items \& remeasurements (vnl. Engelse onderne- } \\
\text { mingen) }\end{array}$ & 5 & & 1 & & - & \\
\hline Special items / other operating income and expenses & 31 & & 13 & & 1 & \\
\hline Special items / bijzondere posten & 48 & 66 & 16 & 22 & 1 & 1 \\
\hline
\end{tabular}

\section{Legenda:}

Adjusted $^{3}$ : aanpassing van het resultaat voor bijzondere posten.

EBITDA (earnings before interest, taxes, depreciation and amortization) = Operationeel resultaat voor interest, belastingen, afschrijving en amortisatie (en afwaarderingen).

EBITA = Operationeel resultaat voor interest, belasting en amortisatie.

Adjusted EBIT = Operationeel resultaat voor bijzondere posten. Andere benamingen zijn: current operating income; operating income recurring, normalized income, trading income.

EBIT = Operationeel resultaat na bijzondere posten. EBIT wordt meestal niet gezien als een alternatieve prestatiemaatstaf.

$\mathrm{EBT}=$ Resultaat voor belastingen .

Resultaat deeln. + jv = resultaat deelnemingen en joint ventures die worden verwerkt volgens de equity method. 
Tabel 3 Aantal genoemde bijzondere posten

\begin{tabular}{|l|c|}
\hline Bijzondere posten & $\mathbf{n}$ \\
\hline Geen & 12 \\
\hline 1 & 1 \\
\hline 2 & 8 \\
\hline 3 & 13 \\
\hline 4 & 25 \\
\hline 5 & 12 \\
\hline 6 & 2 \\
\hline Totaal & 73 \\
\hline
\end{tabular}

Er bestaat een grote variatie in de aard van de posten die in de praktijk als bijzonder worden aangemerkt en hieromtrent bestaat geen eenduidigheid. Dit is mede het gevolg van de beperkte adressering hiervan in IAS 1 .

In tabel 4 geven wij aan welke categorieën bijzondere posten afzonderlijk worden opgenomen in de winsten-verliesrekening of in de toelichting.

Slechts een beperkt deel van de bijzondere posten die worden gerapporteerd in de winst-en-verliesrekening wordt ook afzonderlijk per segment gerapporteerd. Dit heeft te maken met het feit dat bij veel ondernemingen de segmenten worden aangestuurd op basis van resultaten exclusief deze bijzondere posten en deze posten dan ook geen onderdeel uitmaken van de resultaatbegrippen die zijn opgenomen in het segmentatieoverzicht, zie ook paragraaf 3.4.

\section{Figuur 2 Best practice bijzondere posten: Reckitt Benckiser. Annual report and financial statement 2013, p. 55}

\section{Exceptional Items}

Where material, non-recurring expenses or income are incurred during a period, these items are disclosed as exceptional items in the income statement. Examples of such items are:

- Restructuring and other expenses relating to the integration of an acquired business and related expenses for reconfiguration of the Group's activities.

- impairments of current and non-current assets.

- Gains/losses on disposal of businesses.

- Acquisition related costs.

- Costs arising as a result of material and non-recurring regulatory and litigation matters.

The Group also presents an alternative adjusted earnings per share calculation to exclude the impact of the exceptional items.

Management believes that the use of adjusted measures such as adjusted operating profit, adjusted net income and adjusted earnings per share provide additional useful information on underlying trends to Shareholders.

\subsection{De gerapporteerde segmenten}

Volgens IFRS 8 dient bij de extern te rapporteren segmentinformatie te worden uitgegaan van de interne managementinformatie die door de CODM wordt gebruikt voor het beoordelen van de financiële prestaties en het toekennen van middelen (zie paragraaf 2.3). In niet alle

\section{Tabel 4 Welke categorieën bijzondere posten / special items / remeasurements worden opgenomen?}

\begin{tabular}{|c|c|c|}
\hline Naam special item / exceptional items & $n$ & $\%$ \\
\hline Geen melding van special/exceptional items & 11 & 15 \\
\hline Wel melding van special items, maar niet gespecificeerd (1 bedrag gegeven) of nul & 1 & 1 \\
\hline Boekwinsten/verliezen bij afstoting van activa / activiteiten & 48 & 66 \\
\hline Impairments (anders dan goodwill) en reversals & 44 & 60 \\
\hline Impairment van goodwill & 11 & 15 \\
\hline Herstructureringen/ reorganisaties / voorzieningen & 36 & 49 \\
\hline Integratie van nieuwe bedrijfsonderdelen; kosten m.b.t. acquisities & 13 & 18 \\
\hline Voorziening voor juridische claims & 10 & 14 \\
\hline Herwaardering financiële instrumenten / derivaten hedging transactions & 14 & 19 \\
\hline Vreemdevalutaverschillen & 7 & 10 \\
\hline Overheidssubsidies & 4 & 5 \\
\hline Overige ${ }^{5}$ & 41 & 56 \\
\hline Gains > losses: Totaal bijzondere posten is positief & 14 & 19 \\
\hline Gains $<$ losses. Totaal bijzondere posten is negatief & 47 & 64 \\
\hline Niet van toepassing. & 12 & 16 \\
\hline Totaal & 73 & 100 \\
\hline
\end{tabular}


Tabel 5 Wordt gerefereerd aan de CODM ter verduidelijking van aantal gerapporteerde segmenten?

\begin{tabular}{|l|c|c|}
\hline Argumentatie voor aantal gerapporteerde segmenten & $\mathbf{n}$ & $\%$ \\
\hline Ja & 45 & 62 \\
\hline Nee, maar wel verwezen naar interne organisatie- en managementstructuur & 19 & 26 \\
\hline Nee & 9 & 12 \\
\hline Totaal & 73 & 100 \\
\hline
\end{tabular}

jaarrekeningen wordt door middel van referentie aan door de CODM gebruikte informatie gemotiveerd hoe de onderneming is gekomen tot de te rapporteren segmenten en het aantal segmenten(zie tabel 5).

\section{Figuur 3 Best practice uitleg interne organisatiestructuur: Linde, Annual report 2013, p. 199}

\section{[31] Segment information}

IFRS 8 Operating Segments requires operating segments to be defined primarily on the basis of internal management within the organisation. The scope of the financial information prepared for segment reporting corresponds to the information made available on a regular basis to the full Executive Board.

The organisational structure in the gases business is derived from management at regional level. The operating segments within the Gases Division therefore comprise the following eight Regional Business Units (RBUs): North America, South America, Continental \& Northern Europe, Africa \& UK, Middle East \& Eastern Europe, South \& East Asia, Greater China and South Pacific. These operating segments are aggregated to form the following three reportable segments:

$$
\begin{aligned}
& \text { - EMEA \{Europe, Middle East and Africa) } \\
& \text { - Asia / Pacific } \\
& \text { - Americas }
\end{aligned}
$$

The operating segments have comparable economic features and there are no significant differences between the operating segments in terms of products and services, the production process, customer diversification, sales processes or the regulatory environment. Due to the homogeneity between the segments based on the criteria listed above, Linde combines the operating segments according to the responsibilities of individual members of the Executive Board, in order to reflect the internal organisational structure in the external reporting of the Group. The Engineering Division and Other Activities are managed separately on a global basis. In accordance with IFRS 8, The Linde Group therefore reports in five reportable segments. The "Reconciliation" column comprises corporate activities and consolidation adjustments. SEE TABLE 38 ON PAGES 120 TO 121.
Een goed voorbeeld van een duidelijke uitleg over de interne organisatiestructuur en het aantal segmenten is Linde (2013) (zie figuur 3).

Om te kunnen spreken van een operationeel segment moet sprake zijn van een onderdeel dat bedrijfsactiviteiten uitoefent waaruit opbrengsten kunnen worden verdiend en waarbij kosten kunnen worden gemaakt. Activiteiten die niet aan dit criterium voldoen classificeren niet als operationeel segment. Operationele segmenten die niet voldoende omvangrijk zijn om een $10 \%$-drempel (10\% van de omzet, operationeel resultaat of activa) te halen mogen worden samengevoegd tot een te rapporteren segment "Overig”. Een voorbeeld van een goede uitleg vinden we bij Nestlé (zie figuur 4).

Hoofdkantoorfuncties, holdingactiviteiten, financieringsactiviteiten en bepaalde niet aan de segmenten gealloceerde posten zijn voorbeelden van posten die in het segmentatieoverzicht ook regelmatig onder het segment "Overig" worden ondergebracht. Als voorbeelden van niet gealloceerde kosten komen wij bijvoorbeeld kosten van onderzoek en ontwikkeling, impairment van goodwill en immateriële vaste activa, en pensioenkosten tegen. Lail, Thomas $\&$ Winterbotham (2014) wijzen erop dat ondernemingen door gebruik te maken van het segment Overig en daarin overige operationele activiteiten en "corporate" activiteiten te combineren, de prestaties van de gerapporteerde operationele segmenten kunnen maskeren.

In tabel 6 geven wij aan hoe ondernemingen omgaan met het segment "Overig". Het overgrote deel van de ondernemingen kent een segment "Overig" (63 van 73). Maar wat er precies onder valt loopt zeer uiteen.

\section{Figuur 4 Best practice uitleg samenvoeging ope- rationele segmenten. Nestlé, Annual re- port 2013, p. 81}

"Zones and GMB that meet the quantitative threshold of $10 \%$ of sales, trading operating profit or assets, are presented on a stand-alone basis as reportable segments. Other business activities and operating segments, including GMB that do not meet the threshold, like Nestlé Professional, Nespresso and Nestlé Health Science are combined and presented in Other." 


\section{Tabel 6 Posten opgenomen onder (het segment) OTHER in de segmentgegevens}

\begin{tabular}{|l|c|c|}
\hline 1. OTHER bevat alleen de overige activiteiten; daarnaast nog andere kolommen of regels & 3 & \\
\hline (OVERIG) + (ELIM) & 6 & \\
\hline (OVERIG) + (CORP) & 2 & \\
\hline (OVERIG) + (CORP) + (ELIM) & 2 & \\
\hline$($ OVERIG) + (CORP) + (FIN) + (ELIM) & 1 & \\
\hline (OVERIG) + (CORP + FIN) + (ELIM) & 1 & \\
\hline (OVERIG) + (R\&D) + (CORP) + (FIN) & & $15(21 \%)$ \\
\hline
\end{tabular}

\section{Overige activiteiten worden samengevoegd}

\begin{tabular}{|l|c|c|}
\hline (OVERIG + CORP) & 13 & \\
\hline (OVERIG + ELIM) & 2 & \\
\hline (OVERIG + CORP + FIN) & 1 & \\
\hline (OVERIG + CORP) + (ELIM) & 7 & \\
\hline (OVERIG + CORP + ELIM) & 1 & \\
\hline (OVERIG + CORP + FIN) + (ELIM) & 4 & \\
\hline (OVERIG + CORP + FIN + ELIM) & 1 & \\
\hline & & $29(40 \%)$
\end{tabular}

\section{OTHER omvat geen "overige activiteiten"}

CORP (diverse functies; niet duidelijk wat er onder valt, maar waarschijnlijk geen overige activiteiten) (OVERIG) (OTHER, verder niet toegelicht)

\begin{tabular}{|l|l|l|}
\hline ELIM (onduidelijk) & 1 & \\
\hline (CORP) + (ELIM) & 1 & \\
\hline (CORP + ELIM) & 1 & \\
\hline (CORP + FIN) + (ELIM) & 4 & \\
\hline & & $19(26 \%)$ \\
\hline
\end{tabular}

\section{Eén segment of geen segment OVERIG}

\begin{tabular}{|l|c|c|}
\hline Niet van toepassing: 1 segment & 2 & \\
\hline Geen segment OVERIG & 8 & \\
\hline & $10(14 \%)$ \\
\hline Totaal & $73(100 \%)$ \\
\hline
\end{tabular}

\section{Legenda:}

( ) = haken betekent dat gegevens zijn samengevoegd. (OVERIG) + (CORP) betekent dat er twee kolommen of regels zijn opgenomen met een bedrag voor overige activiteiten en een bedrag voor corporate; (OVERIG + CORP) betekent dat in 1 kolom of regel een bedrag wordt genoemd voor overige activiteiten en corporate.

Overig = Overige activiteiten die afzonderlijk niet aan de drempel komen.

CORP = Corporate, hoofdkantoor en overige niet aan operationele segmenten toegerekende opbrengsten en kosten.

FIN = Financieringsaspecten (treasury, insurance).

$R \& D=$ Research and development kosten. ELIM = Eliminaties.

Uit tabel 6 blijkt dat het segment Overig over het algemeen meer bevat dan alleen de resultaten van de operationele segmenten die niet voldoen aan het $10 \%$-criterium en om die reden worden samengevoegd met andere operationele segmenten die onder deze grens blijven. In het segment Overig worden ook di- verse kosten opgenomen die in de interne managementinformatie niet worden toegerekend aan de segmenten. In veel gevallen betreft het bijzondere posten (zie ook tabel 4), maar ook diverse regulier terugkerende kosten, zoals hoofdkantoorkosten, financieringskosten of R\&D-kosten. Daarnaast worden regel- 
Figuur 5 Best practice segment Overig. Eni, annual report 2013, p. 197

\begin{tabular}{|c|c|c|c|c|c|c|c|c|c|}
\hline [€ million] & 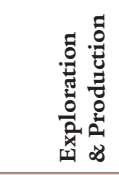 & $\begin{array}{l}\dot{\tilde{J}} \\
\stackrel{\tilde{c}}{0} \\
\stackrel{0}{0} \\
\tilde{y} \\
\tilde{g}\end{array}$ & 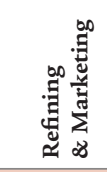 & 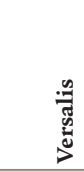 & 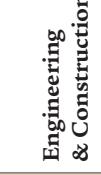 & 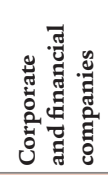 & 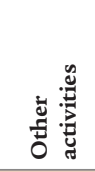 & 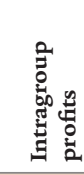 & 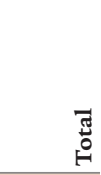 \\
\hline \multicolumn{10}{|l|}{2013} \\
\hline Net sales from operations ${ }^{[a]}$ & 31,268 & 32,124 & 57,329 & 5,859 & 11,611 & 1,453 & 80 & 18 & \\
\hline Less: intersegment sales & {$[18,218]$} & {$[1,215]$} & {$[2,902]$} & [289] & {$[1,018]$} & {$[1,339]$} & [39] & & \\
\hline Net sales to customers & 13,050 & 30,909 & 54,427 & 5,570 & 10,593 & 114 & 41 & 18 & 114,722 \\
\hline Operating profit & 14,871 & {$[2,992]$} & {$[1,517]$} & {$[725]$} & [83] & [399] & {$[337]$} & 38 & 8,856 \\
\hline Provisions for contingencies & 61 & 321 & 100 & 65 & 76 & 178 & 77 & [21] & 857 \\
\hline $\begin{array}{l}\text { Depreciation, amortization } \\
\text { and impairments }\end{array}$ & 7,831 & 2,014 & 942 & 139 & 721 & 61 & 20 & {$[25]$} & 11,703 \\
\hline $\begin{array}{l}\text { Share of profit [loss] of } \\
\text { equity-accounted investments }\end{array}$ & 129 & 101 & 19 & & {$[12]$} & 7 & 8 & & 252 \\
\hline Identifiable assets ${ }^{[b]}$ & 59,811 & 17,349 & 14,531 & 3,169 & 14,271 & 968 & 255 & [793] & 109,561 \\
\hline Unallocated assets & & & & & & & & & 28,527 \\
\hline Equity-accounted investments & 1,730 & 1,561 & 293 & 148 & 166 & & 36 & & 3,934 \\
\hline Identifiable liabilities ${ }^{[c]}$ & 15,645 & 9,591 & 5,974 & 844 & 5,505 & 1,606 & 2,740 & [86] & 41,819 \\
\hline Unallocated liabilities & & & & & & & & & 35,095 \\
\hline Capital expenditures & 10,475 & 232 & 619 & 314 & 902 & 190 & 21 & [3] & 12,750 \\
\hline
\end{tabular}

[a] Before elimination of intersegment sales.

[b] Includes assets directly associated with the generation of operating profit.

[c] Includes liabilities directly associated with the generation of operating profit.

matig eliminaties tussen de segmenten opgenomen onder het segment Overig.

Van de 63 ondernemingen die een segment Overig rapporteren (categorie $1 \mathrm{t} / \mathrm{m} 3$ ) rapporteren 48 ondernemingen (76\%) een negatief resultaat voor dit segment. Dit laat zien dat het in het segment Overig gerapporteerde resultaat sterk wordt beïnvloed door het negatieve resultaateffect van de hiervoor genoemde posten die in veel gevallen worden meegenomen in het resultaat van het segment Overig en eventuele positieve resultaten van de hierin opgenomen kleinere segmenten meer dan compenseren.

Vanuit het oogpunt van transparantie en informatieverschaffing over alternatieve winstbegrippen in de segmentinformatie zien wij in deze presentatiewijze de volgende bezwaren:

- De benaming van de gerapporteerde prestatiemaatstaf van de individuele segmenten dekt niet de lading. Bij goede lezing van de segmentinformatie blijkt bijvoorbeeld de EBIT van een segment eigenlijk de EBIT voor bijzondere posten en niet gealloceerde optie- en pensioenkosten te zijn. Een lezer van de jaarrekening of het persbericht kan hierdoor op het verkeerde been worden gezet als hij zich focust op de EBIT van de belangrijkste segmenten.

- Er wordt geen inzicht gegeven in de prestaties van de segmenten die onder de grens blijven om individueel gerapporteerd te worden. Samenvoeging van deze kleinere operationele segmenten neemt weliswaar in- formatie weg doordat de lezer de prestaties van deze segmenten slechts geaggregeerd kan beoordelen, maar geeft nog wel informatie over de gecombineerde prestaties van die entiteiten. Indien die resultaten echter worden gecombineerd met een grote diversiteit aan niet aan de andere segmenten toegerekende kosten dan is het onmogelijk om überhaupt nog een zinvol beeld te krijgen over de prestaties van die segmenten.

- De posten die worden meegenomen in het segment Overig betreffen feitelijk de posten die het verschil vormen tussen het totaal van het resultaat van de segmenten en het geconsolideerde resultaat en dat zou duidelijk tot uitdrukking moeten komen in de in IFRS 8 voorgeschreven aansluiting. Deze aansluiting wordt niet verstrekt doordat de aansluitposten worden gecombineerd met het segment Overig.

\subsection{Winstbegrippen in het segmentatieoverzicht}

IFRS 8 eist dat in de gesegmenteerde gegevensverstrekking in de jaarrekening de resultaatmaatstaven worden gerapporteerd die intern worden gebruikt door de CODM ten behoeve van het beoordelen van operationele segmenten en het alloceren van middelen aan de segmenten. Het aantal financiële prestatiemaatstaven dat in de segmentatieoverzichten wordt vermeld is aanzienlijk. Tabel 7 biedt een overzicht van het aantal winstbegrippen in het segmentatieoverzicht en tabel 8 geeft inzicht in de aard van de winstbegrippen die worden gebruikt door de onderzochte ondernemingen. Dit zijn alleen de winstbegrippen waarvoor bedragen per segment worden genoemd. 
Tabel 7 Aantal gerapporteerde winstbegrippen per onderneming in het segmentatieoverzicht

\begin{tabular}{|l|c|c|}
\hline & $\mathbf{n}$ & $\mathbf{\%}$ \\
\hline 1 & 17 & 23 \\
\hline 2 & 31 & 42 \\
\hline 3 & 12 & 16 \\
\hline 4 & 7 & 10 \\
\hline 5 & 2 & 3 \\
\hline 6 & 1 & 1 \\
\hline 7 & 3 & 4 \\
\hline Totaal & 73 & 100 \\
\hline
\end{tabular}

Uit tabel 8 blijkt dat er een grote variëteit is aan financiële prestatiemaatstaven die door ondernemingen worden gebruikt voor het beoordelen van de performance van segmenten. Als we niet alleen naar de inhoud van de begrippen kijken, maar ook naar de benaming ${ }^{7}$ dan is de variëteit van de gehanteerde maatstaven nog een veelvoud van wat in tabel 8 wordt getoond. Dit is een direct gevolg van IFRS 8 die voorschrijft om de resultaatsmaatstaven te rapporteren die de CODM gebruikt bij het aansturen van de onderneming en haar segmenten. Het management onder- bouwt in veel gevallen het gebruik van de alternatieve financiële prestatiemaatstaven op basis van de informatieve waarde voor gebruikers, die immers "through the eyes of management" hun oordeel kunnen vormen over de performance van de onderneming. Zie figuur 6 op pag. 440.

Indien het management van de onderneming alternatieve winstbegrippen rapporteert, dan dient een aansluitingsoverzicht te worden opgenomen naar het geconsolideerde IFRS-resultaat voor of na belasting zoals dat blijkt uit de geconsolideerde winst-en-verliesrekening. De mate van detail waarin inzicht wordt gegeven in de posten die het verschil tussen beide winstbegrippen verklaren is wisselend. Hierbij verwijzen wij ook naar onze bevindingen in paragraaf 3.3 waaruit blijkt dat veel ondernemingen (een deel van) deze aansluitverschillen "verstoppen" in het segment Overig. Novartis is een goed voorbeeld van een onderneming die gedetailleerd inzicht geeft in de aansluiting tussen het geconsolideerde resultaat en het totaal van het voor de segmenten gerapporteerde "core result". Hierbij merken wij wel op dat deze aansluiting is opgenomen in het bestuursverslag aangezien Novartis dit "core result" in het bestuursverslag per segment rapporteert, maar niet over dit winstbegrip rapporteert in de segmentinformatie in de jaarrekening (Zie figuur 7 op pag. 441)

\section{Tabel 8 Aard van gerapporteerde winstbegrippen in het segmentatieoverzicht}

\begin{tabular}{|c|c|c|}
\hline Naam winstbegrip in geconsolideerde winst-en-verliesrekening en segmentatieoverzicht & $\begin{array}{l}\text { Aantal w } \\
\text { segment } \\
\text { tatie-ove }\end{array}$ & $\begin{array}{l}\text { pen per } \\
\text { egmen- }\end{array}$ \\
\hline & $\mathrm{n}$ & $\%$ \\
\hline Brutowinst & 6 & 8 \\
\hline Adjusted EBITDA (excl. resultaat deeln \& jv) & 13 & \\
\hline Adjusted EBITDA (incl. resultaat deeln \& jv) & 2 & \\
\hline Adjusted EBITDA (geen resultaat deeln \& jv) & 1 & \\
\hline Adjusted EBITDA & 16 & 22 \\
\hline EBITDA (excl. resultaat deeln \& jv) & 8 & \\
\hline EBITDA (incl. resultaat deeln \& jv) & - & \\
\hline EBITDA (geen resultaat deeln \& jv) & 1 & \\
\hline EBITDA & 9 & 12 \\
\hline Adjusted EBITA (excl. resultaat deeln \& jv) & 2 & \\
\hline Adjusted EBITA (incl. resultaat deeln \& jv) & - & \\
\hline Adjusted EBITA (geen resultaat deeln \& jv) & - & \\
\hline Adjusted EBITA & 2 & 3 \\
\hline EBITA (excl. resultaat deeln \& jv) & 1 & \\
\hline EBITA (incl. resultaat deeln \& jv) & 1 & \\
\hline EBITA (geen resultaat deeln \& jv) & - & \\
\hline EBITA & 2 & 3 \\
\hline
\end{tabular}




\begin{tabular}{|c|c|c|}
\hline Adjusted EBIT (excl. resultaat deeln \& jv) & 25 & \\
\hline Adjusted EBIT (incl. resultaat deeln \& jv) & 6 & \\
\hline Adjusted EBIT (geen resultaat deeln \& jv) & 5 & \\
\hline Adjusted EBIT & 36 & 50 \\
\hline EBIT (excl. resultaat deeln \& jv) & 26 & \\
\hline EBIT (incl. resultaat deeln \& jv) & 15 & \\
\hline EBIT (geen resultaat deeln \& jv) & 8 & \\
\hline EBIT (incl. resultaat deeln \& jv) + resultaat op verkoop en sluiting business unit & 1 & \\
\hline EBIT & 50 & 68 \\
\hline Adjusted EBT & - & 0 \\
\hline EBT (excl. resultaat deeln \& jv) & - & \\
\hline EBT (incl. resultaat deeln \& jv) & 2 & \\
\hline EBT (geen resultaat deeln \& jv) & 2 & \\
\hline EBT & 4 & 5 \\
\hline Earnings on current cost of supplies basis & 1 & \\
\hline Adjusted net income & 1 & \\
\hline Nettowinst, continuing operations & 1 & \\
\hline Nettowinst (excl. resultaat deeln. + jv) & - & \\
\hline Resultaat op basis van U.S. GAAP & 1 & \\
\hline Diverse winstbegrippen & 4 & 5 \\
\hline Nettowinst & 4 & 5 \\
\hline Adjusted EBITDA van niet-geconsolideerde deelnemingen en joint ventures (equity method) & 1 & \\
\hline Adjusted EBIT van niet-geconsolideerde deeln. \& jv (equity method) & 1 & \\
\hline Totaal Resultaat niet-geconsolideerde deelnemingen \& joint ventures (equity method) & 2 & 3 \\
\hline Discontinued operations (beëindigde activiteiten, na belastingen) & - & 0 \\
\hline Other non-recurring operating income (vnl. Franse ondernemingen) & 2 & \\
\hline Special items \& remeasurements (vnl. Engelse ondernemingen) & 1 & \\
\hline Special items / other operating income and expenses & 14 & \\
\hline Special items / bijzondere posten & 17 & 23 \\
\hline
\end{tabular}

Legenda:

Adjusted: aanpassing van het resultaat voor bijzondere posten.

EBITDA (earnings before interest, taxes, depreciation and amortization) = Operationeel resultaat voor interest, belastingen, afschrijving en amortisatie (en afwaarderingen).

$\mathrm{EBITA}=$ Operationeel resultaat voor interest, belasting en amortisatie.

Adjusted EBIT = Operationeel resultaat voor bijzondere posten. Andere benamingen zijn: current operating income; operating income recurring, normalized income, trading income.

$\mathrm{EBIT}=$ Operationeel resultaat na bijzondere posten. EBIT wordt meestal niet gezien als een alternatieve prestatiemaatstaf.

$\mathrm{EBT}=$ Resultaat voor belastingen.

Resultaat deeln. + jv $=$ resultaat deelnemingen en joint ventures die worden verwerkt volgens de equity method. 


\section{Figuur 6 Best practice motivering informatieve waarde alternatieve financiële prestatiemaatstaven. Bayer, Annual report 2013 Augmented version, p. 171.}

\subsection{Calculation of EBIT(DA) Before Special Items}

Key performance indicators for the Bayer Group are EBIT before special items and EBITDA before special items. These indicators are reported in order to allow a more accurate assessment of business operations. The special items - comprising effects that are non-recurring or do not regularly recur or attain similar magnitudes - are detailed in the following table. EBITDA, EBITDA before special items and EBIT before special items are not defined in the International Financial Reporting Standards and should therefore be regarded only as supplementary information. EBITDA before special items is a meaningful indicator of operating performance since it is not affected by depreciation, amortization, impairment losses, impairment loss reversals or special items. By reporting this indicator, the company aims to give readers a clear picture of the results of operations and ensure comparability of data over time. The EBITDA margin before special items, which is the ratio of EBITDA before special items to sales, serves as a relative indicator for the internal and external comparison of operational earning power.

De situatie die we zien bij Novartis, waarbij in het bestuursverslag een grotere variëteit van winstbegrippen wordt gerapporteerd per segment dan in de jaarrekening zien we bij meer ondernemingen. Een aantal ondernemingen vermijdt het gebruik van alternatieve winstbegrippen in de jaarrekening zelfs volledig, terwijl in het bestuursverslag analyses van de resultaten van segmenten plaatsvinden die verder gaan dan de jaarrekening en waarbij wel alternatieve winstbegrippen worden gebruikt. Deze praktijk treffen wij vooral aan bij Duitse ondernemingen, zoals BASF, Bayer Group, BMW en Daimler.

Het aantal winstbegrippen dat in het bestuursverslag wordt gepresenteerd is veel uitgebreider dan in het segmentatieoverzicht. Vaak treffen wij analyses aan (bij 20 ondernemingen) waarbij resultaten gecorrigeerd worden voor valuta-effecten (constant currency basis) of consolidatie-effecten (constant scope of consolidation), zodat een betere vergelijking van de prestaties in de tijd en tussen segmenten onderling mogelijk is. Ook troffen wij twee ondernemingen aan die in het segmentatieoverzicht een onaangepast operationeel resultaat (EBIT) per segment vermelden, terwijl in het bestuursverslag een begrip als "core earnings" wordt gehanteerd. Dit roept de vraag op, op basis van welke prestatiemaatstaven de CODM nu daadwerkelijk de prestaties van de segmenten beoordeelt en of deze maatstaven vervolgens, in overeenstemming met IFRS 8 , worden gerapporteerd in de segmentinformatie in de jaarrekening. Mogelijk komt deze terughoudendheid bij het rapporteren van alternatieve winstbegrippen in de jaarrekening voort uit de kritiek en zorgen die vanuit verschillende hoeken zijn geuit met betrek- king tot het gebruik ervan, zie ook paragraaf 2.2.

De meest uitgebreide aansluitinformatie troffen wij, weliswaar buiten de jaarrekening, aan bij Siemens (zie figuur 8 op pag. 442).

Op de webpagina staat een 18 pagina's tellend document waarin een lijst van "mogelijke" non-GAAP financial supplemental measures is opgenomen en waarbij aansluitingsoverzichten worden gegeven naar IFRS-maatstaven.

\section{Samenvatting en conclusies}

Op basis van IFRS 8 moet een onderneming gesegmenteerde informatie geven die aansluit op de basis waarop het management (de CODM) de prestaties van de onderneming beoordeelt en beslissingen neemt over het toewijzen van middelen. De interne managementinformatie is dus leidend voor de extern te rapporteren segmentinformatie. De resultaatmaatstaven op basis waarvan het management de segmenten aanstuurt wijken in veel gevallen af van de nettowinst zoals die onder IFRS wordt gerapporteerd. Vaak worden bepaalde posten buiten beschouwing gelaten en in sommige gevallen wordt het resultaat zelfs op een andere basis bepaald.

Een logisch gevolg daarvan is dat de gesegmenteerde informatie die op basis van IFRS 8 wordt verschaft over het algemeen alternatieve winstbegrippen bevat. Hierbij constateren wij wel enige terughoudendheid bij ondernemingen. Meerdere ondernemingen rapporteren een aantal alternatieve winstbegrippen in het bestuursverslag terwijl zij geen of minder alternatieve winstbegrippen rapporteren in het segmentatieoverzicht in de jaarrekening.

Een duidelijke omschrijving die de lading dekt en duidelijke aansluiting tussen de gehanteerde alternatieve winstbegrippen en het geconsolideerde IFRS resultaat zijn belangrijke aandachtspunten voor transparante informatieverschaffing over de segmentprestaties.

Wij constateren dat ondernemingen, waar van toepassing, een aansluiting opnemen tussen het totale resultaat van de segmenten en het geconsolideerde IFRS-resultaat. Op één punt concluderen wij echter dat de transparantie over gesegmenteerde resultaten belangrijk kan toenemen. Het betreft hier het gebruik van het segment Overig. Dat segment is bedoeld voor de geaggregeerde informatie over de kleinere operationele segmenten (segmenten die onder de 10\% grenzen blijven). In de praktijk worden onder deze noemer echter ook diverse andere posten opgenomen zoals niet-gealloceerde (holding) kosten, bijzondere posten en eliminaties. Dit heeft een aantal consequenties voor de transparantie van de informatieverschaffing over de operationele segmenten. Ten eerste vertroebelt dit het gedetailleerde inzicht in de aansluitverschillen tussen de segmentresultaten en het 


\section{Figuur 7 Best practice aansluitoverzicht alternatief winstbegrip: Novartis, Annual report 2013, p. 178-181}

2013 AND 2012 RECONCILIATION OF IFRS RESULTS TO CORE RESULTS

\begin{tabular}{|c|c|c|c|c|c|}
\hline $\begin{array}{l}\text { IERS results } \\
\text { USD millions }\end{array}$ & $\begin{array}{r}\text { Amortization } \\
\text { of intangible } \\
\text { assetsts }{ }^{1} \\
\text { USD millions }\end{array}$ & $\begin{array}{l}\text { Impairments }^{2} \\
\text { USD millions }\end{array}$ & $\begin{array}{r}\text { Acquisition or } \\
\text { divestment } \\
\text { related items, } \\
\text { restructuring } \\
\text { and integration } \\
\text { charges } \\
\text { USD millions } \\
\text { USD }\end{array}$ & $\begin{array}{r}\text { Other } \\
\text { exceptional } \\
\text { items } \\
{ }^{4} \\
\text { USD millions }\end{array}$ & $\begin{array}{r}\text { Core results } \\
\text { USD millions } \\
\end{array}$ \\
\hline Gross profit & 2866 & 28 & & 41 & 42158 \\
\hline Operating income & 2955 & 259 & 331 & 30 & 14485 \\
\hline Income before taxes & 3214 & 259 & 349 & 74 & 14631 \\
\hline-1443 & & & & & $-2098^{5}$ \\
\hline Net Income & & & & & 12533 \\
\hline Basic earnings per share (USD) ${ }^{6}$ & & & & & 5.09 \\
\hline \multicolumn{6}{|l|}{ The following are adjustments to arrive at Core Gross Profit } \\
\hline Cost of goods sold & 2866 & 28 & & 41 & -16673 \\
\hline \multicolumn{6}{|l|}{ The following are adjustments to arrive at Core Operating Income } \\
\hline Marketing \& Sales & & & & 27 & -14522 \\
\hline Research \& Development & 85 & 86 & & 39 & -9642 \\
\hline General \& Administration & & & & 25 & -3035 \\
\hline Other income & & -53 & & -506 & 808 \\
\hline Other expense & 4 & 198 & 331 & -404 & -1282 \\
\hline \multicolumn{6}{|l|}{ The following are adjustments to arrive at Core Income before taxes } \\
\hline Income from associated companies & 259 & & 18 & & 877 \\
\hline Other financial income and expense & & & & & -48 \\
\hline \multicolumn{6}{|c|}{ 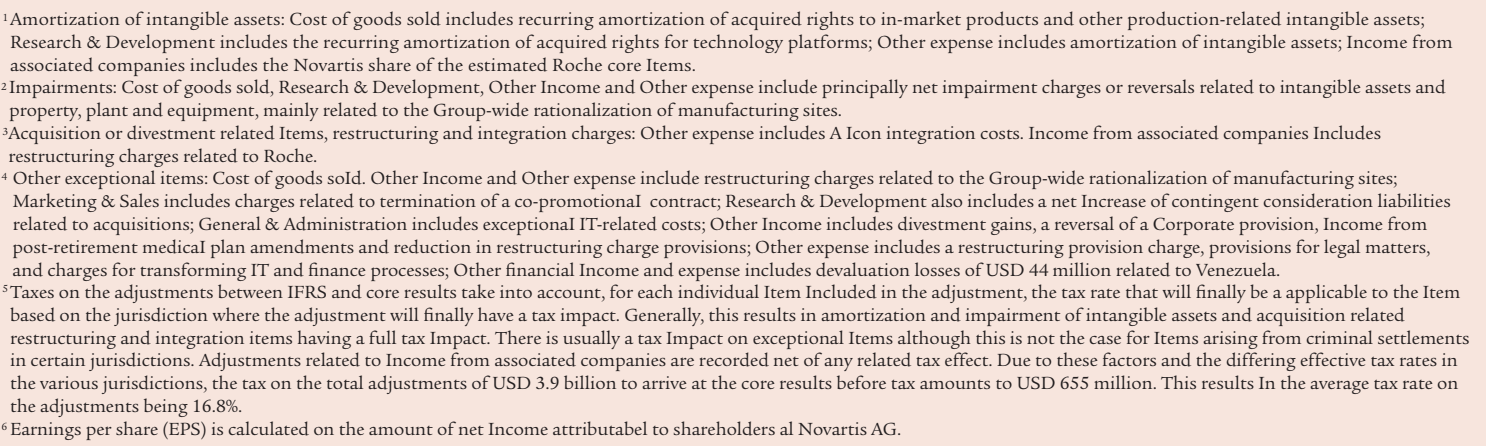 } \\
\hline
\end{tabular}

2013 AND 2012 RECONCILIATION OF SEGMENT OPERATING INCOME TO CORE OPERATING INCOME

\begin{tabular}{|c|c|c|c|c|}
\hline & \multicolumn{2}{|c|}{ Pharmaceuticals } & \multicolumn{2}{|c|}{ Alcon } \\
\hline & $\begin{array}{r}2013 \\
\text { USD millions }\end{array}$ & $\begin{array}{r}2012 \\
\text { USD millions }\end{array}$ & $\begin{array}{r}2013 \\
\text { USD millions }\end{array}$ & $\begin{array}{r}2012 \\
\text { USD millions }\end{array}$ \\
\hline Operating Income & 9376 & 9598 & 1232 & 1465 \\
\hline \multicolumn{5}{|l|}{ Impairments } \\
\hline Intangible assets & 29 & 211 & 57 & 17 \\
\hline $\begin{array}{l}\text { Property, plant \& equipment related to the Group-wide } \\
\text { rationalization of manufacturing sites }\end{array}$ & 1 & & & \\
\hline Total Impairment charges & 74 & 238 & 61 & 17 \\
\hline \multicolumn{5}{|l|}{ Acquisition-related items } \\
\hline - Expense & & & 330 & 264 \\
\hline Total acquisition-releated items, net & & & 330 & 264 \\
\hline \multicolumn{5}{|l|}{ Other exceptional Items } \\
\hline Exceptional divestrment gains & -313 & -93 & & \\
\hline - Expense & 33 & 19 & & \\
\hline Additional exceptional Income & -70 & -137 & -56 & \\
\hline Additional exceptional Income & -63 & 96 & 61 & 14 \\
\hline Total other exceptional Items & -205 & 55 & 82 & 37 \\
\hline Total adjustments & 147 & 615 & 2462 & 2233 \\
\hline Core operating Income & 9523 & 10213 & 3694 & 3698 \\
\hline Core return on net sales & $29.6 \%$ & $31.8 \%$ & $35.2 \%$ & $36.2 \%$ \\
\hline
\end{tabular}

Other income and other expense have been restated by an additional USD 318 million expense (USD 235 million after taxes) to reflect the adoption of revised IAS 19 on Employee Benefits (see pages 247 and 248 ). 
Figuur 8 Melding alternatieve winstbegrippen. Siemens, Non-GAAP financial measures

\begin{abstract}
Orders; Adjusted or organic growth rates of revenue and orders; Total Sectors profit; ROCE (adjusted); Free cash flow; Adjusted EBITDA; Adjusted industrial net debt are or may be non-GAAP financial measures. Definitions of these supplemental financial measures, a discussion of the most directly comparable IFRS financial measures, information regarding the usefulness of Siemens' supplemental financial measures, the limitations associated with these measures and reconciliations to the most comparable IFRS financial measures are available on our Investor Relations website under WWW.SIEMENS.COM/NONGAAP.
\end{abstract}

geconsolideerde resultaat. Ten tweede zorgt dit er in veel gevallen voor dat de benaming van het winstbegrip van de afzonderlijk gerapporteerde segmenten de lading onvoldoende dekt aangezien uit de benaming niet blijkt dat dit winstbegrip exclusief een aantal specifieke posten is weergegeven. Ten derde zorgen deze posten ervoor dat geen inzicht wordt gegeven in de geaggregeerde prestaties van de kleinere segmenten aangezien die prestaties worden vermengd met de hiervoor genoemde kostenposten die geen verband hebben met de prestaties van die segmenten.

Ten behoeve van de transparante informatieverschaffing over de segmentresultaten bevelen wij dan ook aan om duidelijkheid over de samenstelling van het segment Overig te verschaffen en te waarborgen dat deze in de toekomst slechts nog de resultaten van operationele segmenten bevat. Overige, niet aan operationele segmenten gealloceerde, posten dienen dan opgenomen te worden als onderdeel van een gedetailleerde aansluiting tussen het totaal van de resultaten van de operationele segmenten en het geconsolideerde IFRS-resultaat.

Dr A.J. Brouwer RA is partner binnen het National Office en de Capital Markets and Accounting Advisory praktijk van PwC. Hij is tevens verbonden aan de Universiteit van Amsterdam.

Dr C.D. Knoops is assistent professor Financial Accounting Theory aan de Erasmus School of Economics van de Erasmus Universiteit Rotterdam.

De auteurs danken Lisa Anna Enting, Hicham El-Mahtouchi, Jeansy Martina en Suut-wah Tang voor hun assistentie bij het onderzoek.

Noten

1 Investment funds zijn hierop een uitzondering. 2. Bij de telling hebben wij alle winstbegrippen meegenomen, die ook in tabel 2 staan. Dus ook winstbegrippen als "resultaat uit hoofde van deelnemingen en joint ventures die worden verantwoord volgens de equity methode" en resultaat na belasting van beëindigde bedriffsactiviteiten (discontinued operations). Een ander winstbegrip dat is meegenomen in de telling is "other operating income" (dat een aantal keren voorkomt bij) Franse ondernemingen), "special items and remeasure- ments" (dat een aantal keren voorkomt bij Engelse ondernemingen) en benoeming van special items in de winst-en-verliesrekening. Voor een overzicht van alle getelde winstbegrippen, zie tabel 2 .

3 Ondernemingen gebruiken verschillende benamingen, zoals 'normalised', ' underlying', 'recurring', 'core'.

4 Impairments worden niet meer als voorbeeld genoemd in de nieuwe aanbeveling van 2013. De eisen zijn strenger geworden t.0.v. de aanbeveling uit 2009.
Indien meer dan 1 andere bijzondere post wordt genoemd, is dit geteld als 1 .

6. De aantallen en percentages komen overeen met tabel 2, respectievelijk de optelling van de aantallen in kolom 4 en 6 en de optelling van de percentages in kolom 5 en 7.

- Zie noot 3. In het bestuursverslag vinden vaak nog analyses plaats waarbij rekening wordt gehouden met bijvoorbeeld valuta-effecten of consolidatie-effecten; zie verder in paragraaf 3.4.

\section{Literatuur}

- Autorité des Normes Comptables (2013), Recommandation no 2013-03 du 7 novembre 2013. Relative au format des comptes consolidés des entreprises établis selon les normes comptables internationals (hors établissements du secteur bancaire et organismes d'assurance). Geraadpleegd op http:// www.anc.gouv.fr/files/live/sites/anc/files/ contributed/Normes\%20francaises/Recommandations/REC02010_2014/REC02013/
Recommandation_2013_R03/Recommandation_2013_R03.pdf.

- Backhuijs, J.B., \& Camfferman, K. (2011). Gesegmenteerde gegevensverstrekking volgens IFRS 8. Maandblad voor Accountancy en Bedriffseconomie, 85(1/2), 21-36.

- Backhuijs, J.B., \& Knoops, C.D. (2011). Keuzes en alternatieven in de presentaties van de primaire overzichten onder IFRS. Maandblad voor Accountancy en Bedriffseconomie,
85(12), 589-607.

- Backhuijs, J.B., \& Mertens, G.M.H. (2000). De presentatie winst en verliesrekening. In J. Dijksma, J.A.G.M. Koevoets \& R.G.A. Vergoossen (redactie). Het jaar 1999 verslagen. Onderzoek jaarverslaggeving Nederlandse ondernemingen (pp. 110-133). Deventer: Kluwer.

- Bhattacharya, N., Black, E.L., Christensen, T.E., \& Mergentahler, R.D. (2004). Empirical 
evidence on recent trends in pro forma reporting. Accounting Horizons, 18(1), 27-43.

- Bosman, R.G., \& Vergoossen, R.G.A. (2007). Persberichten over jaarcijfers. In R.G. Bosman, C. Camfferman en R.G.A. Vergoossen (redactie). Het jaar 2006 verslagen, Onderzoek jaarverslaggeving ondernemingen (pp. 13-27), Deventer: Kluwer.

- Brouwer, A.J. (2007a), De winst is goed, maar hoe is de performance? Controllers Magazine, 21(3, maart), 35-38.

- Brouwer, A.J. (2007b). Rapportage over prestaties in de Europese Unie: Babylonische spraakverwarring? Maandblad voor Accountancy en Bedrijfseconomie, 81(6), 259-268.

- Brouwer, A.J., \& Gup, B.E. (2009). EBITDA: Down but not out. In R. Thomas \& B.E. Gup (eds). The valuation handbook. Hoboken, New Jersey: John Wiley \& Sons, Inc.

- Choi, Y-S., \& Young, S. (2015). Transitory earnings components and the two faces of nongenerally accepted accounting principles earnings. Accounting and Finance, 55(1), 75-103.

- Committee of European Securities Regulators (2005). CESR Recommendation on alternative performance measures. Geraadpleegd op http://www.esma.europa.eu/system/ files/05_178b.pdf.

- Conseil National de la Comptabilité (2009). Recommandation № 2009-R-03 du 2 Julliet 2009 relative au format des états financiers des enterprises sous referential comptable international (hors enterprises de banque et d'assurance). Geraadpleegd op http://www. anc.gouv.fr/files/live/sites/anc/files/contributed/Normes\%20francaises/Recommandations/Recomm2009_r03.pdf.

- Dijksma, J., \& Schoonderbeek, W.J. (2001). Segmentatie. In J.A.G.M. Koevoets, G.M.H Mertens en R.G.A. Vergoossen (redactie). Het jaar 2000 verslagen - Onderzoek jaarverslaggeving Nederlandse ondernemingen (pp. 4965). Deventer: Kluwer.

- Entwistle, G.M., Feltham, G., \& Mbagwu, C.
(2005). The voluntary disclosure of pro forma earnings: A U.S.-Canada comparison. Journal of International Accounting Research, 4(2), $1-23$.

- European Securities and Markets Authority (ESMA) (2014). Consultation Paper - ESMA Guidelines on Alternative Performance Measures. Geraadpleegd op http://www.esma. europa.eu/system/files/esma-2014-175_cp_ on_the_draft_guidelines_on_apms.pdf.

- Financial Accounting Standards Board (FASB) (2002), Summary of User Interviews - Reporting Financial Performance by Business Enterprises. Geraadpleegd op www.fasb.org/project/interviews.pdf.

- Financieele Dagblad, Het (FD) (2004). Ebitda is voor ons buiten de orde - NIVRA: Jaarverslagen wemelen van onvolkomenheden en foute begrippen, 14 januari, p. 11.

- Financieele Dagblad, Het (FD) (2013). Wildgroei aan winstbegrippen kan belegger op verkeerde been zetten, 17 januari 2013.

- Hooghiemstra, R.B.H., \& Tas, L.G. van der (2003). Rapportering over financial performance. In J.B. Backhuijs, R.G. Bosman en C.D. Knoops (redactie). Het jaar 2002 verslagen, Onderzoek jaarverslaggeving Nederlandse ondernemingen (pp. 73-100). Deventer: Kluwer.

- Hooghiemstra, R.B.H., \& Tas, L.G. van der (2004). Informatieverschaffing over prestatieindicatoren. In J.B. Backhuijs, R.G. Bosman en C. Camfferman (redactie). Het jaar 2003 verslagen, Onderzoek jaarverslaggeving Nederlandse ondernemingen (pp. 91-118). Deventer: Kluwer.

- International Accounting Standards Board (2013a). A review of the conceptual framework for financial reporting. Discussion paper DP/2013/1. Geraadpleegd op www. frrs.org.

- International Accounting Standards Board (2013b). Report and feedback statement Post-implementation Review: IFRS 8 Operating Segments. Geraadpleegd op www.ifrs. org.
- International Accounting Standards Board (2014). Exposure Draft ED/2014/1 - Disclosure Initiative Proposed amendments to IAS 1. Geraadpleegd op www.ifrs.org.

- International Organization of Securities Commissions, IOSCO Technical Committee (2002). Cautionary statement regarding non-GAAP results measures. Geraadpleegd op http:// www.iosco.org/news/pdf/IOSCONEWS4.pdf.

- Isidro, H., \& Marques, A. (2015). The role of institutional and economic factors in the strategic use of non-GAAP disclosures to beat earnings benchmarks. European Accounting Review, 24(1), 95-128.

- Knoops, C.D., \& Dijksma, J. (1996). Gesegmenteerde gegevensverstrekking. In M.N. Hoogendoorn, J.A.G.M. Koevoets en R.G.A. Vergoossen (redactie). Het jaar verslagen Onderzoek jaarverslaggeving 1995 (pp. 3565). Deventer: Kluwer.

- Lail, B.E., Thomas, W.B., \& Winterbotham, G.J. (2014). Classification shifting using the "Corporate/Other" segment. Accounting Horizons, 28(3), 455-477.

- Marseille, E.A., \& Vergoossen, R.G.A. (2005). Het gebruik van alternatieve financiële prestatie-indicatoren in persberichten. Maandblad voor Accountancy en Bedrifseconomie, 79(5), 196-204.

- PwC (2014). Corporate performance: What do investors want to know? Reporting adjusted performance measures. Geraadpleegd op https://www.pwc.com/gx/en/audit-services/ corporate-reporting/publications/investorview/assets/pwc-investors-survey-powerfulstories-through-integrated-reporting.pdf.

- Securities and Exchange Commission (SEC) (2001). Division of Corporation Finance: Frequently Requested Accounting and Financial Reporting Interpretations and Guidance, 31 maart 2001. Geraadpleegd op www.sec.gov.

- Securities and Exchange Commission (SEC) (2003). Conditions for use of non-GAAP financial measures. Geraadpleegd op https://www. sec.gov/rules/final/33-8176.htm. 


\section{Bijlage Ondernemingen waarvan de jaarrekening is onderzocht}

\begin{tabular}{|c|c|c|c|}
\hline Nr. & Company & Bedrijfstak & Land \\
\hline 1 & A P Moller - Maersk A & Industrial transportation & Denemarken \\
\hline 2 & ASML Holding & Electronic \& electrical equipment & Nederland \\
\hline 3 & Air Liquide & Chemicals & Frankrijk \\
\hline 4 & Airbus Groupe NV & Aerospace \& defence & Frankrijk \\
\hline 5 & Anglo American & Mining & Verenigd Koninkrijk \\
\hline 6 & Anheuser-Busch InBev & Beverages & België \\
\hline 7 & Associated British Foods & Food producers & Verenigd Koninkrijk \\
\hline 8 & AstraZeneca & Pharmaceuticals \& biotechnology & Verenigd Koninkrijk \\
\hline 9 & Atlas Copco A & Industrial engineering & Zweden \\
\hline 10 & BASF & Chemicals & Duitsland \\
\hline 11 & BG Group & Oil \& gas producers & Verenigd Koninkrijk \\
\hline 12 & BHP Billiton & Mining & Verenigd Koninkrijk \\
\hline 13 & BMW & Automobiles \& parts & Duitsland \\
\hline 14 & BP & 0il \& gas producers & Verenigd Koninkrijk \\
\hline 15 & BT Group & Telecomms & Verenigd Koninkrijk \\
\hline 16 & Bayer AG & Pharmaceuticals \& biotechnology & Duitsland \\
\hline 17 & British American Tobacco & Tobacco & Verenigd Koninkrijk \\
\hline 18 & Christian Dior & Personal goods & Frankrijk \\
\hline 19 & Continental & Automobiles \& parts & Duitsland \\
\hline 20 & Daimler AG & Automobiles \& parts & Duitsland \\
\hline 21 & Danone & Food producers & Frankrijk \\
\hline 22 & Deutsche Post & Commercial transportation & Duitsland \\
\hline 23 & Deutsche Telekom & Telecomms & Duitsland \\
\hline 24 & Diageo & Beverages & Verenigd Koninkrijk \\
\hline 25 & E.ON & Electricity & Duitsland \\
\hline 26 & EDF Group & Electricity & Frankrijk \\
\hline 27 & Enel & Electricity & Italië \\
\hline 28 & Eni & Oil \& gas producers & Italië \\
\hline 29 & Ericsson B & Telecomms & Zweden \\
\hline 30 & GDF SUEZ & Electricity & Frankrijk \\
\hline 31 & GlaxoSmithKline & Pharmaceuticals \& biotechnology & Verenigd Koninkrijk \\
\hline 32 & Glencore Xstrata & Mining & Verenigd Koninkrijk \\
\hline 33 & Heineken NV & Beverages & Nederland \\
\hline 34 & Henkel KG Pref & Chemicals & Duitsland \\
\hline 35 & Hennes \& Mauritz B & Retailers & Zweden \\
\hline 36 & Hermes International S.C.A. & Leisure goods & Frankrijk \\
\hline 37 & Iberdrola & Electricity & Spanje \\
\hline 38 & Imperial Tobacco Group & Tobacco & Verenigd Koninkrijk \\
\hline 39 & Inditex & Personal goods & Spanje \\
\hline 40 & Koninklijke Philips NV & Electronic \& electrical equipment & Nederland \\
\hline 41 & L'Oreal & Personal goods & Frankrijk \\
\hline 42 & LVMH & Leisure goods & Frankrijk \\
\hline
\end{tabular}




\begin{tabular}{|c|c|c|c|}
\hline Nr. & Company & Bedriffstak & Land \\
\hline 43 & Linde & Industrial engineering & Duitsland \\
\hline 44 & National Grid & Electricity & Verenigd Koninkrijk \\
\hline 45 & Nestlé & Food producers & Zwitserland \\
\hline 46 & Novartis (REGD) & Pharmaceuticals \& biotechnology & Zwitserland \\
\hline 47 & Novo-Nordisk B & Pharmaceuticals \& biotechnology & Denemarken \\
\hline 48 & Orange & Telecomms & Frankrijk \\
\hline 49 & Pernod Ricard & Beverages & Frankrijk \\
\hline 50 & Reckitt Benckiser Group & Household goods & Verenigd Koninkrijk \\
\hline 51 & Repsol & Oil \& gas producers & Spanje \\
\hline 52 & Richemont A (Br) & Personal goods & Zwitserland \\
\hline 53 & Rio Tinto & Mining & Verenigd Koninkrijk \\
\hline 54 & Roche HIdgs (GENUS) & Pharmaceuticals \& biotechnology & Zwitserland \\
\hline 55 & Royal Dutch Shell A & Oil \& gas producers & Verenigd Koninkrijk \\
\hline 56 & SABMiller & Beverages & Verenigd Koninkrijk \\
\hline 57 & SAP & Software \& computer services & Duitsland \\
\hline 58 & Sanofi & Pharmaceuticals \& biotechnology & Frankrijk \\
\hline 59 & Schneider Electric & Technoloy hardwae \& equipment & Frankrijk \\
\hline 60 & Siemens AG & Electronic \& electrical equipment & Duitsland \\
\hline 61 & Statoil ASA & Oil \& gas producers & Noorwegen \\
\hline 62 & Syngenta & Forestry \& paper & Zwitserland \\
\hline 63 & Telefonica & Telecomms & Spanje \\
\hline 64 & Telenor A/S & Mobile telecommunications & Noorwegen \\
\hline 65 & TeliaSonera & Mobile telecommunications & Zweden \\
\hline 66 & Tesco & Food and drug retailers & Verenigd Koninkrijk \\
\hline 67 & Total & Oil \& gas producers & Frankrijk \\
\hline 68 & Unilever & Household goods & Verenigd Koninkrijk \\
\hline 69 & Vinci & Construction \& materials & Frankrijk \\
\hline 70 & Vivendi & Mobile telecommunications & Frankrijk \\
\hline 71 & Vodafone Group & Mobile telecommunications & Verenigd Koninkrijk \\
\hline 72 & Volkswagen & Automobiles \& parts & Duitsland \\
\hline 73 & Volvo B & Automobiles \& parts & Zweden \\
\hline
\end{tabular}

